AC 2011-1230: AN UNDERGRADUATE RESEARCH PROJECT: THE DESIGN AND DEVELOPMENT OF AN ENVIRONMENT FRIENDLY HYBRID BOAT

Faruk Yildiz, Sam Houston State University

Keith L. Coogler, Sam Houston State University

Mr. Keith L. Coogler is an instructor of industrial technology at Sam Houston State University. He received a BS in Design \& Development and holds a MA in Industrial Education and is pursuing an Ed.D. in Higher Education from Texas A\&M University Commerce. His primary teaching area is Construction Management. Research interests include: automation, electronics, alternative energy, and "green" construction.

Ayhan Zora, Deere \& Company

(C)American Society for Engineering Education, 2011 


\section{An Undergraduate Research Project: The Design and Development of an Environment Friendly Hybrid Boat}

As the concern for environmental protection of the Earth increases, clean renewable energy resources attract more attention. The technical development of renewable energy such as solar energy, wind energy, wave energy, thermoelectric energy, and kinetic energy (human power) are being pursued on an ever-growing basis. One example of a renewable energy source used for everyday living is the possibility of a propulsion system that combines renewable energy sources (wind, solar, and human power) with the hydrogen fuel cell system for a kind-to-theenvironment hybrid boat. Boats which run on battery power have existed for some time. However, the low energy-density in batteries has made it difficult for applications to a larger ship. Accordingly, a system which can be applied to a battery-powered boat has been developed, known as Hybrid Electric Boat (HEB). An 18 ft-length Pursuit 2000 S2 boat was converted to be completely battery powered, with the batteries charged by renewable energy systems such as solar and hydrogen fuel cell systems. A new energy storage and conversion system for the boat hybrid propulsion has been implemented by Industrial Technology students. The project team has confidence that theoretical studies which dovetail with the project would be beneficial for the students' scientific knowledge. Experimental studies completed as part of the project would provide contributions to our national HEB design.

\section{Introduction}

Legislation for air emissions and water pollution is getting more restrictive for lakes and fresh waterways. Fuel Cell (FC) technology is a solution to replace internal combustion engines, based on gasoline for fuel. With better efficiency, zero emissions, and almost zero noise, FC or hybrid boats offer a viable alternative that delivers effective motorized navigation while protecting fresh water drinking resources. It is expected that as the development of electric boats increases, these findings will contribute to the knowledge impacting environmental issues and will reduce the use of oil.

As traditional non-renewable energy sources are dwindling and concerns over environmental pollution are rising everyday due to increased use of fossil fuels, the focus of the automotive and boat industry have shifted to production of hybrid electric vehicles that are more energy efficient and have less green house gas emission rates. In particular, there is an educational and industrial increase in hybrid and electric boat projects ${ }^{[1-5]}$. The first electric boat was developed by Moritz von Jacobi in 1839 in St Petersburg, Russia, a 24-foot boat which carried 14 passengers at $3 \mathrm{mph}$. However, it took more than 30 years of battery and motor development before this craft began to be deployed in any numbers. In 1886, an electric boat crossed the English Channel in both directions in 8 hours. By 1889, the first 6 electric charter boats were working on the Thames and at the 1893 Chicago World Fair 55, boats carried more than a million passengers ${ }^{[6]}$. In the US, the Electric Boat Company was founded in 1899 and built the first submarine which was purchased by the U.S. Navy in 1900. Since then, electric power has been used almost exclusively for powering submarines underwater, although diesel was used for powering them on the surface until the development of diesel-electric transmission by the US Navy in 1928. The Electric Boat Company eventually became General Dynamics Corporation in $1952^{[7]}$. 
The use of combined fuel and electric propulsion has gradually been extended over the years to the extent that some modern liners such as the Queen Mary 2 use only electric motors, powered by diesel and gas turbine engines. The advantages include being able to run the fuel engines at an optimal speed at all times and being able to mount the electric motor in a pod which may be rotated by $360^{\circ}$ for increased maneuverability. The use of electricity alone to power boats stagnated apart from their outboard use as trolling motors until the Californian firm of Duffy started producing small electric craft in $1968^{[8]}$. It was not until the 1980s that the Electric Boat Association was formed and production of solar powered boats began. While most boats on the water today are powered by diesel engines and sail power (gasoline engines are also popular) it is perfectly feasible to power boats by electricity. Electric boats were very popular from the 1880s until the 1920s, when the internal combustion engine took dominance. Since the energy crises of the 1970s, once more interest in this silent, non-polluting and renewable energy source has been increasing steadily. With the present state of technological development, many believe that the time is right for electric boats to become popular again.

The electrification of boats is vital to improve the air quality of the environment, reduction of gas use, and to help reduction of $\mathrm{CO}_{2}$ gases which harm ozone layers and the environment. There is

an increasing market for small size electric boats that run on batteries ${ }^{[6-10]}$. Due to limited energy density in the batteries and slow development of battery technology, larger sized electric boats or ships have not been developed, are not commonly used, and not available on the market ${ }^{[10]}$. One of the power sources for an electric boat is a hydrogen fuel cell system, which is becoming popular. Hydrogen fuel cells might be the next revolution in transportation, because this is a low cost, zero emissions solution to our dependency on oil. Essentially, hydrogen fuel cells work by converting compressed hydrogen gas into electricity using a polymer electrolyte membrane, with only byproducts of heat and water. Hydrogen is also the most abundant chemical element in the universe, occupying $75 \%$ of the entire universe's elemental mass. There are already commercial and educational examples of hydrogen fuel cell powered boats on the market ${ }^{[11-15]}$.

An increasing quantity of alternative energy resources presents much promise for our society. Due to this fact, the next generation of students will need more curricular support in this area, especially for those students engaged in engineering and technology programs. In order to motivate students and make them more involved in the research of hybrid and electric vehicle technology and to foster new ideas from the students, the Industrial Technology program organizes regular meetings and workshops to increase student interest in renewable energy technologies. This project was accomplished by students majoring in different fields. One of the major goals of this project was training and education of engineering and technology students in renewable energy applications. Students from different major and minors (Design and Development, Electronics, Construction Management, Computer Science, Industrial Technology) participated in different phases of this research project and successfully completed their parts.

\section{Conversion of Engine to Electric Motor}

An $18 \mathrm{ft}$-length Pursuit 2000 S2 boat with a V6 Envirude gasoline engine was donated to the Industrial Technology program in spring 2010. The V6 engine was broken and badly rusted due to Hurricane Ike that had occurred in Southeast Texas and Louisiana in 2008. Since then, boat 
trailer and propeller sections were in the water and corrosion developed between the engine, midsection (exhaust), and propeller section mounts. Students were able to separate the engine from the propeller and exhaust section and applied major modifications to recover the lower section of the engine. The recovered Envirude motor propeller section is in the process of being modified with major changes to use as a backup unit for the boat. As a replacement, a smaller unit, an old Mercury 200 (20 HP) outboard engine that had been donated from a local boat shop, was converted to an electric motor (EMC-R brush type permanent magnet DC motor). This engine was preferred due to its smaller propeller and shaft that fit with the electric motor drive properly. For the electric motor mounting purposes, a mounting adapter was designed and manufactured by a faculty member and students to mount a DC motor to the propeller unit and connect shafts. After removing the gasoline engine from the propeller unit and shaft, the propeller shaft was connected to the motor shaft by two couplers. The shaft couplers were purchased and carefully welded together to form one piece. The motor coupler is a critical component of the drive train, through which all torque is transmitted. It was mounted to the front face of the traction motor. The specifications, pictures, and mounting adapter drawing are provided in Figures 1,2,3,4 respectively.
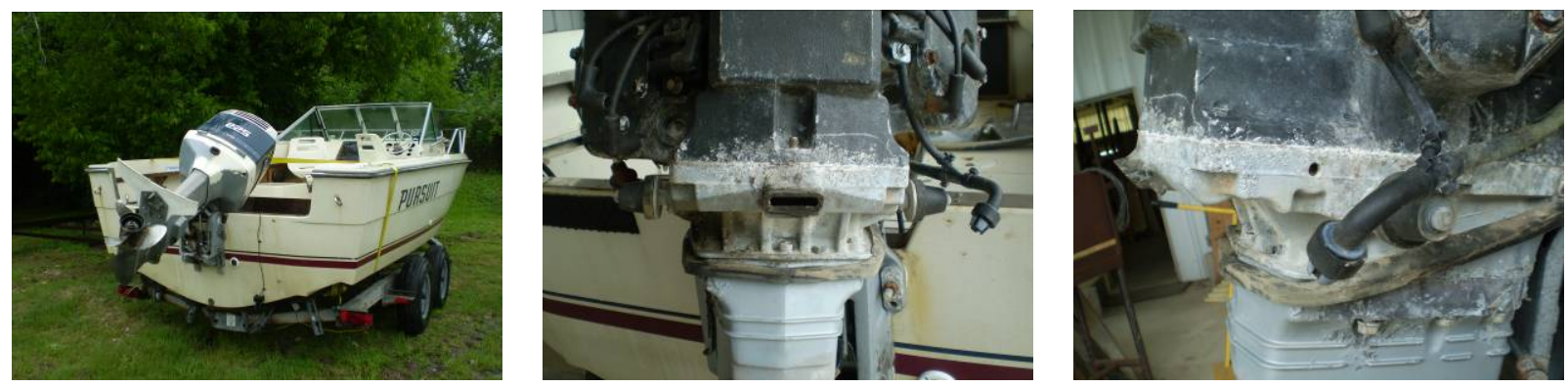

Figure 1: Pursuit 2000 Boat with rusted V6 Envirude engine
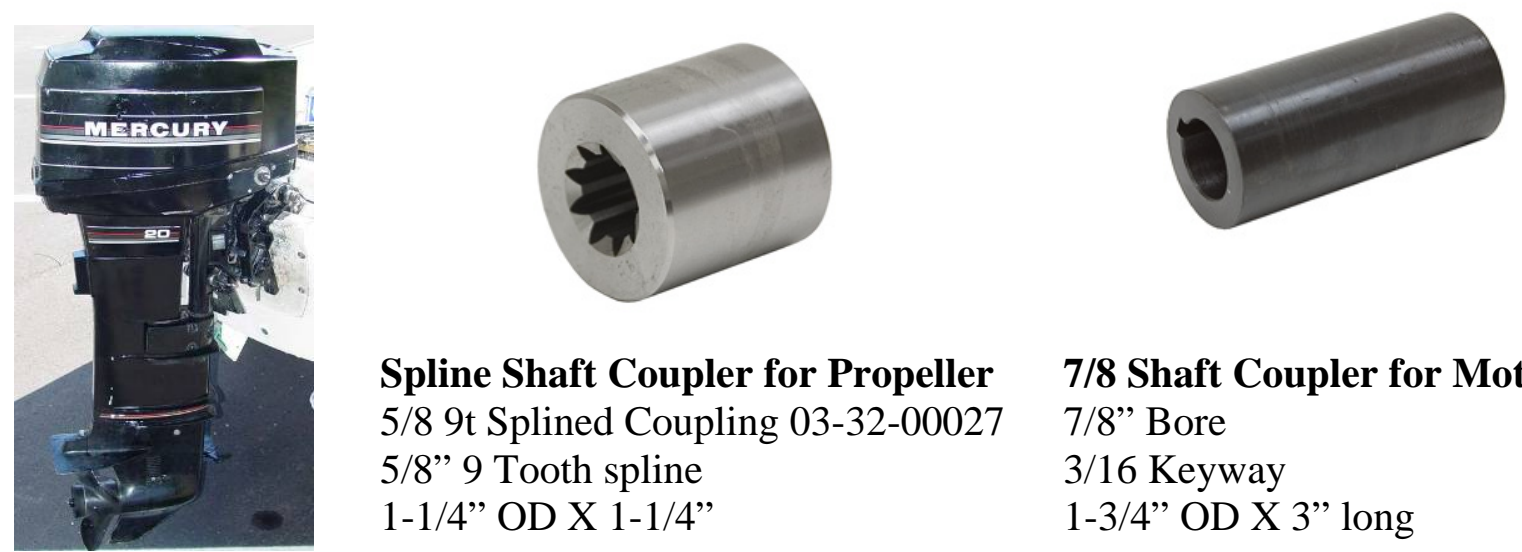

Spline Shaft Coupler for Propeller

5/8 9t Splined Coupling 03-32-00027

5/8" 9 Tooth spline

1-1/4” OD X 1-1/4”
7/8 Shaft Coupler for Motor

7/8” Bore

3/16 Keyway

1-3/4” OD X 3” long

Figure 2a: Mercury 200 outboard motor, 2b: propeller shaft coupler, 2c: motor shaft coupler 

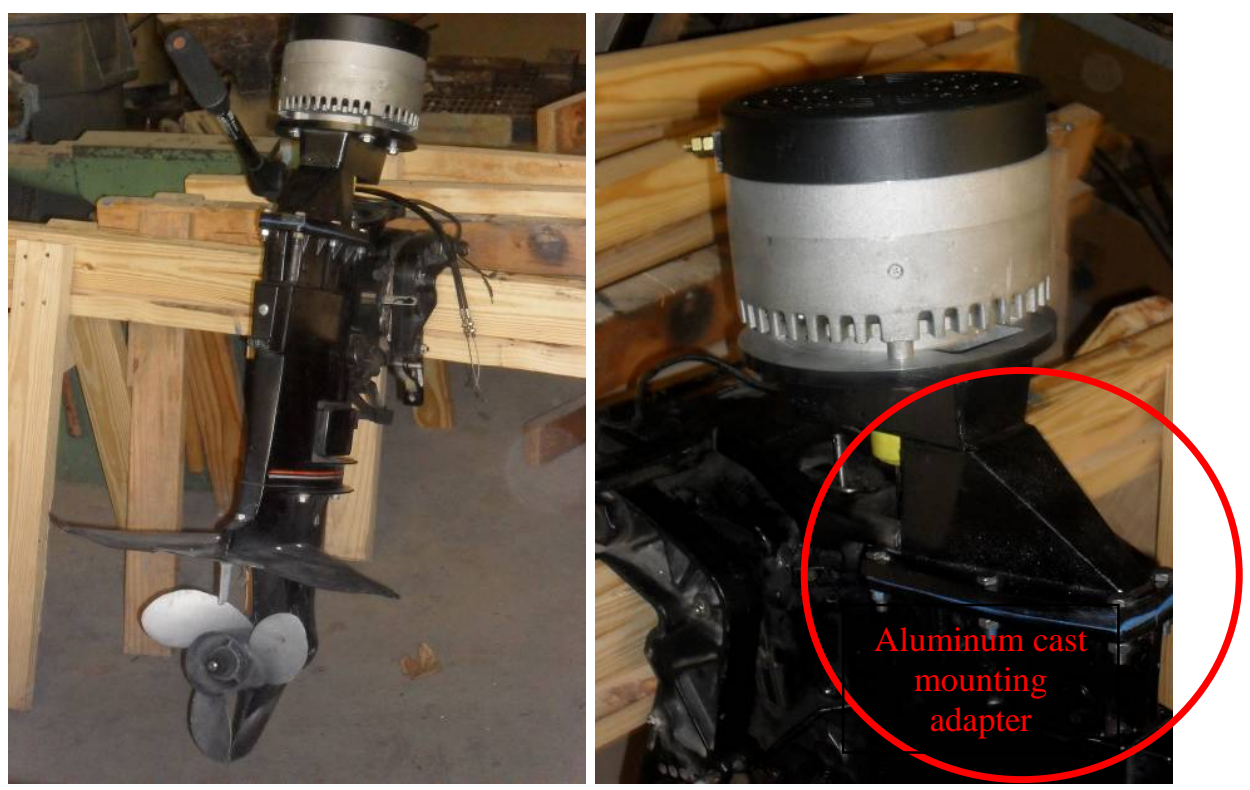

Figure 3: Traction motor mounted on the modified mercury motor with manufactured adapter

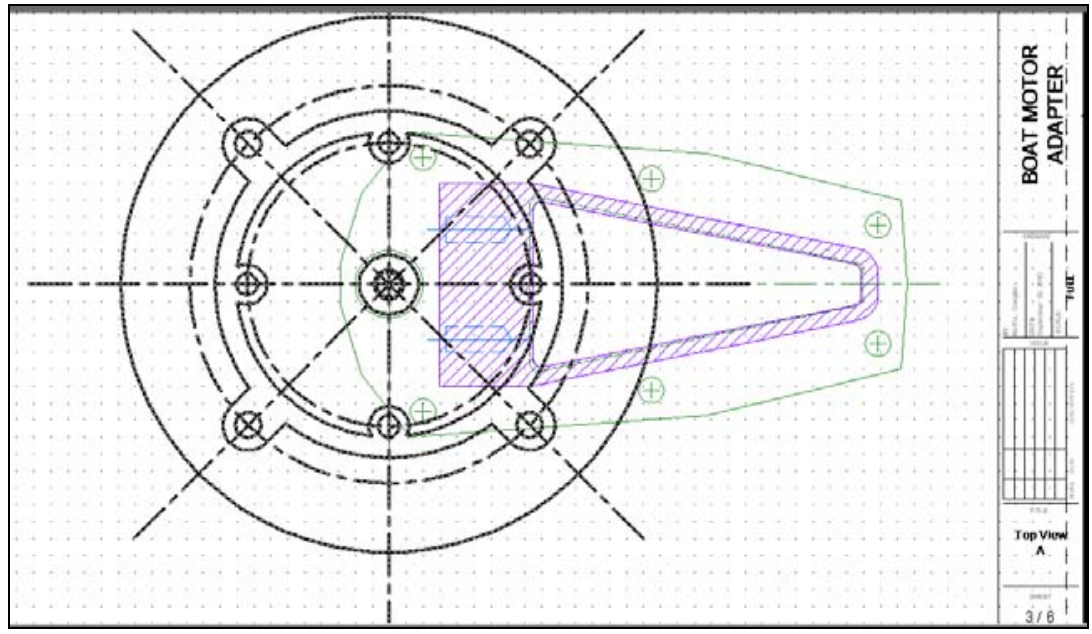

Figure 4: The AutoCAD drawing of motor mount adapter

\section{Electric Motor Drive}

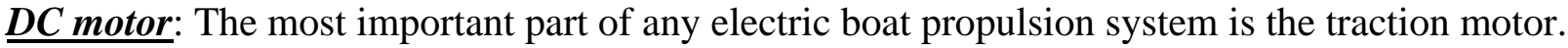
It is the motor that converts the electrical energy into mechanical energy. The challenge was to select a traction motor that could satisfactorily meet the performance requirements set in the project. A permanent magnet DC motor (48V) was chosen as the motor type. Most commonly used traction motors for electric vehicles are series DC motor, AC induction motor, or permanent magnet synchronous motor. However, for this project, a permanent magnet DC motor was selected mainly because of PM and DC characteristics ${ }^{[16]}$, which make the design of the power electronic controller simple. Other benefits that permanent magnet motors provide are the following: a) Since the flux is produced by the permanent magnet, there is no need for an 
external flux control circuit, b) because there is no field circuit, the permanent magnet motor does not have any field copper losses like shunt DC motors would have ${ }^{[17]}$, c) since no field windings are required, permanent magnet motors are smaller in size compared to shunt DC motors ${ }^{[18]}$. The basic configuration and picture of a permanent magnet DC motor is shown in Figure 5.

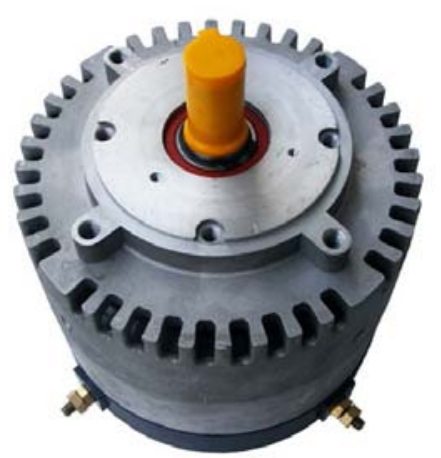

Power: 8 cont-- $15 \mathrm{pk}$ hp

Voltage: 48 Volt rated

Current: $148 \mathrm{~A}$

Torque: $160 \mathrm{lb}$

Speed: 3500 rpm @ 48v unloaded Size: 8" OD, 5.5" long (w/o shaft) Shaft: 7/8"x 1-3/4", 3/16" key

Weight: 28 lbs

Figure 5: ETEK (EMCR-R brush type) permanent magnet DC electric motor ${ }^{[19]}$

For the electric drive purposes, an ETEK (EMCR-R brush type) permanent magnet DC electric motor was implemented to the system. Students connected a motor shaft to the propeller shaft properly to receive maximum efficiency. This radial motor can reach up to $150 \mathrm{~A}$ at $48 \mathrm{~V}$ in continuous use and runs in either direction, is ideally suited for $24 \mathrm{~V}$ DC drive systems, and works with Alltrax or any other PM motor controller. The potential applications are electrathons, motorcycles, go-karts, ride-on trains, boats, and robots. Figure 6 shows manufacturer power characteristics of the motor ${ }^{[20]}$.

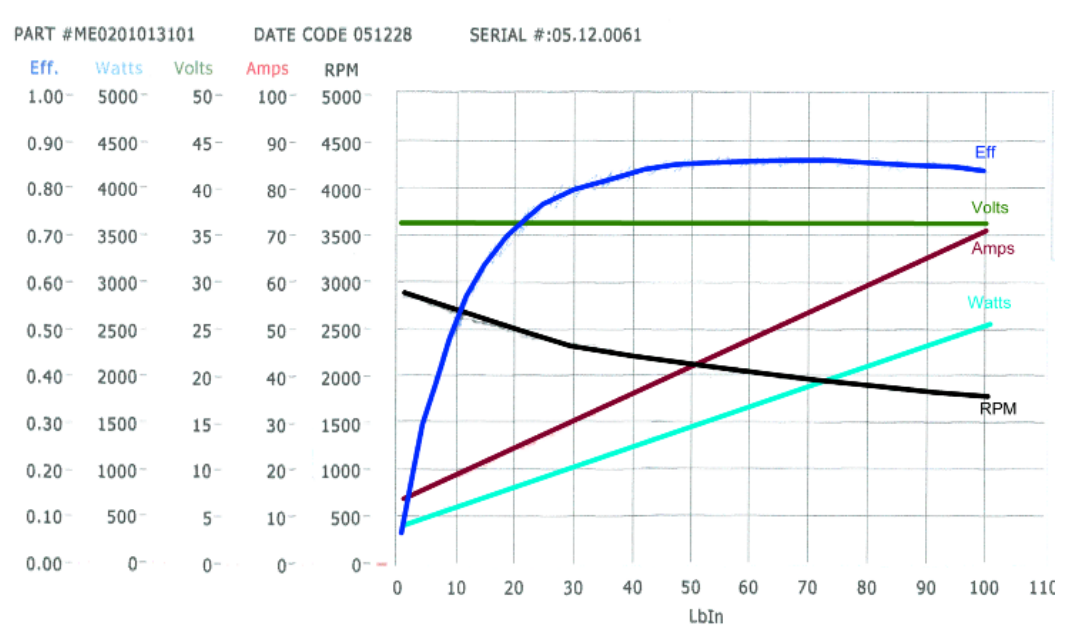

Figure 6: Motor power manufacturer characteristics ${ }^{[20]}$

Throttle: An EZ-GO “Pot Box" variable resistor (potentiometer) throttle was implemented within the system to control the speed of the boat. This pot box (potentiometer) throttle is the industry standard for electric golf carts and electric automobiles and is a two-wire pot box with a micro-switch designed to work with various controllers on AC and DC vehicles. A potentiometer has a built-in return spring and connects directly to the existing boat throttle cable. The basic configurations and picture of an EZ-GO potentiometer throttle are shown in Figure $7^{[21]}$. 


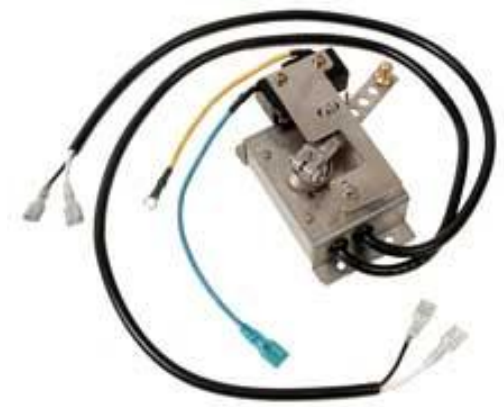

Approx. Size: 3.75 in $\mathrm{H} \mathrm{x} 4$ in W x 2 in D Weight: $14 \mathrm{oz}$.

Resistance: 0 - 5k ohms

Figure 7: EZ-GO Throttle and basic specifications

Motor Controller and Contactor: The motor controller delivers current to the electric motor and controls the motor voltage. The controller should also have the ability to protect against overrevving, self over-heating, and contactor failure. Few options exist for high-current motor controllers in the electric vehicle field. Alltrax, PG Drives, Sevcon, Curtis, DCP, and CafeElectric DC motor controllers exist with current capabilities of 250A or higher. An Alltrax AXE 4834 motor controller was added to the motor drive unit with a contactor unit and a fuse ${ }^{[22-}$ ${ }^{24]}$. Contactors (also known as solenoids) are used to connect and disconnect the main battery bus power. The contactor engages or disengages the power at the flip of a switch when it is time to turn the motor on or off. This is very useful in an emergency situation when the main power needs to be turned off quickly and easily. DC contactors are electromechanical products developed and produced for the purpose of high current switching between a power source and a load. Trombetta "Bear" contactors feature strong construction and high current carrying capability. In addition, an appropriate pre-charge resistor and a contactor coil suppression diode were used with the contactor system connected to motor controller unit. The basic specifications and pictures of motor control units, fuse, and contactor are shown in Figure 8.

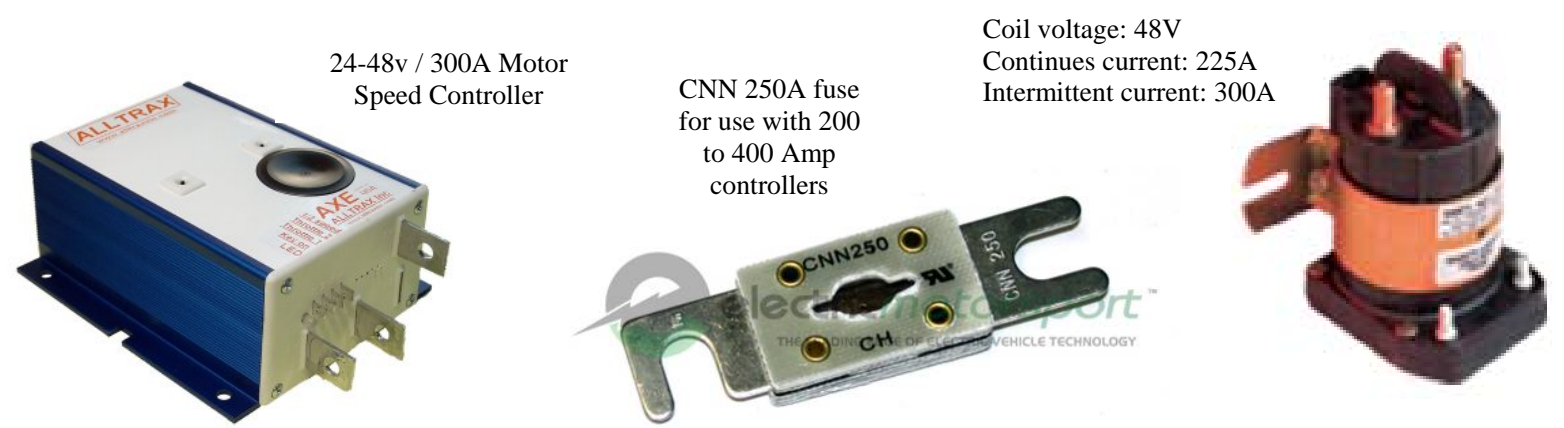

Figure 8: Motor controller, fuse, and contactor basic specifications

The following block diagram (Figure 9) shows a conceptual illustration of the DC traction motor controller design (motor drive) after introduction of major components of the motor drive unit. 


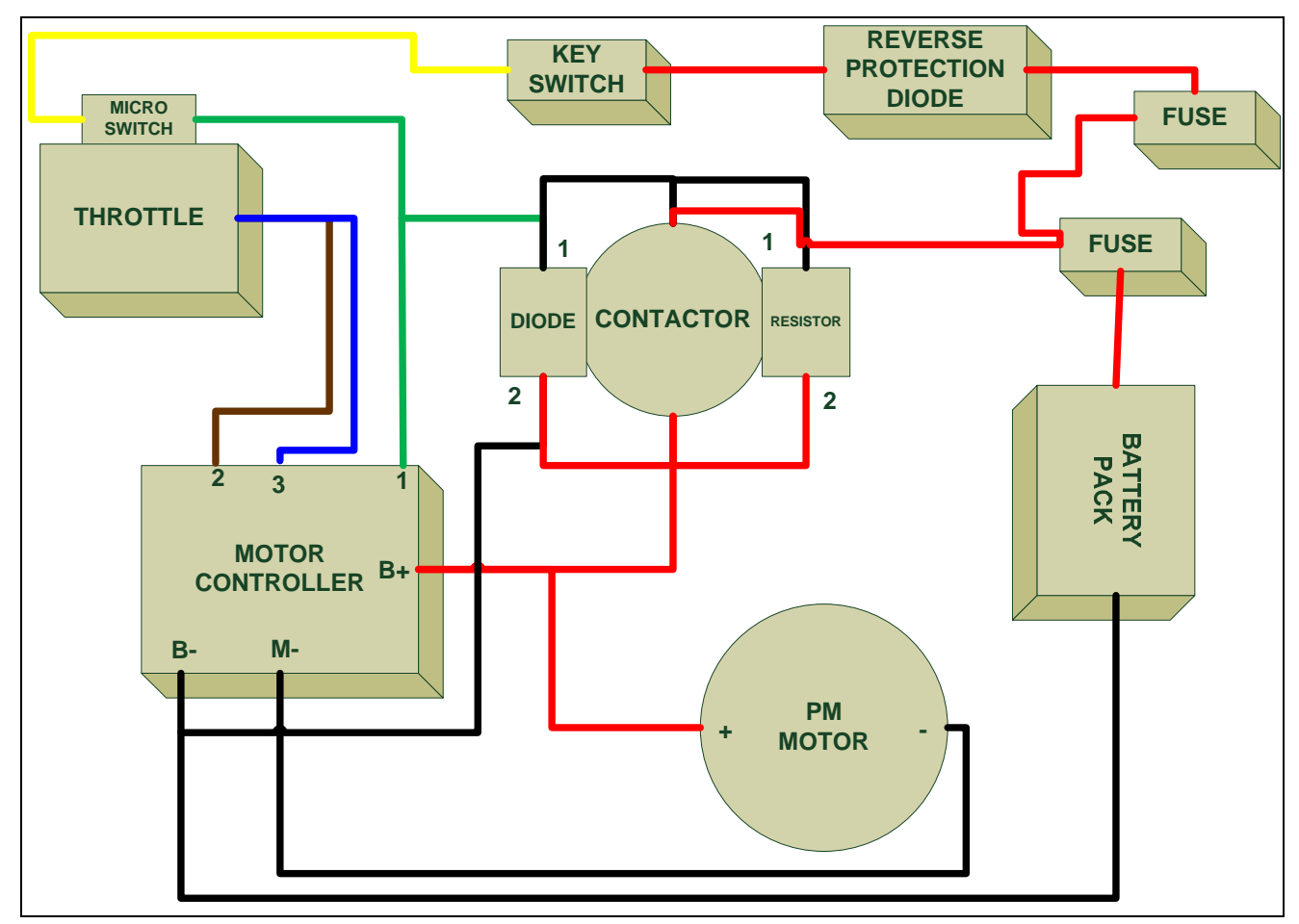

Figure 9: Conceptual illustration of the DC traction motor controller

\section{Power Generation Systems}

In this section, two alternative energy sources (solar and hydrogen fuel cell) to charge batteries are explained in detail. The implementation of the each alternative energy source has been conducted by students majoring or minoring in Industrial Technology. Students are teamed according to their interest and knowledge levels as part of their classes.

\section{Hydrogen Fuel Cell System:}

A hydrogen fuel cell unit (Horizon H-1000 fuel stack) was connected to run both as a back-up and a main energy source to charge batteries or to power the electric boat directly through a motor control unit. The price of this unit was satisfactory when compared with other products in the market (\$3600). The criteria to select this product were a)low cost, b)high efficiency, c)light weight, d)small size e)simple to connect and easy to integrate. The specification of the hydrogen fuel cell is summarized in Table $1^{[25-26]}$. Figures 10,11 show the hydrogen gas canister and $1 \mathrm{~kW}$ hydrogen fuel cell systems. 
Table 1: Technical Specifications of H-1000 Fuel Cell System ${ }^{\text {[25-26] }}$

\begin{tabular}{|c|c|}
\hline Type of fuel cell & PEM \\
\hline Number of cells & 72 \\
\hline Rated power & 1000W \\
\hline Rated performance & 43V@23.5A \\
\hline Output voltage range & $39 V-69 V$ \\
\hline Weight (with fan \& casing) & $4.2 \mathrm{~kg}(9.3 \mathrm{lbs})$ \\
\hline Size & $256 \times 220 \times 122 \mathrm{~mm}(12.8 \times 8.7 \times 4.8 \mathrm{in})$ \\
\hline Reactants & Hydrogen and Air \\
\hline Rated $\mathrm{H} 2$ consumption & $14 \mathrm{~L} / \mathrm{min}$ \\
\hline Hydrogen pressure & $0.5-0.6 \mathrm{Bar}(7.2-9.4 \mathrm{PSI})$ \\
\hline Controller weight & $0.45 \mathrm{~kg}$ (0.99lbs) \\
\hline Hydrogen supply valve voltage & $12 \mathrm{~V}$ \\
\hline Purging valve voltage & $12 \mathrm{~V}$ \\
\hline Blower voltage & $6-12 \mathrm{~V}$ \\
\hline Ambient temperature & $5-30^{\circ} \mathrm{C}\left(41-86^{\circ} \mathrm{F}\right) \mathrm{v}$ \\
\hline Max stack temperature & $65^{\circ} \mathrm{C}\left(149^{\circ} \mathrm{F}\right)$ \\
\hline Hydrogen purity & $99.999 \%$ dry H2 \\
\hline Humidification & Self-humidified \\
\hline Cooling & Air (integrated cooling fan) \\
\hline Start up time & Immediate \\
\hline \multirow[t]{2}{*}{ Efficiency of system } & 40\%@43V \\
\hline & $\begin{array}{l}\text { The flow rate may change whin the power ourpur } \\
\text { "systiem elecuronics need exiermal power supply }\end{array}$ \\
\hline
\end{tabular}
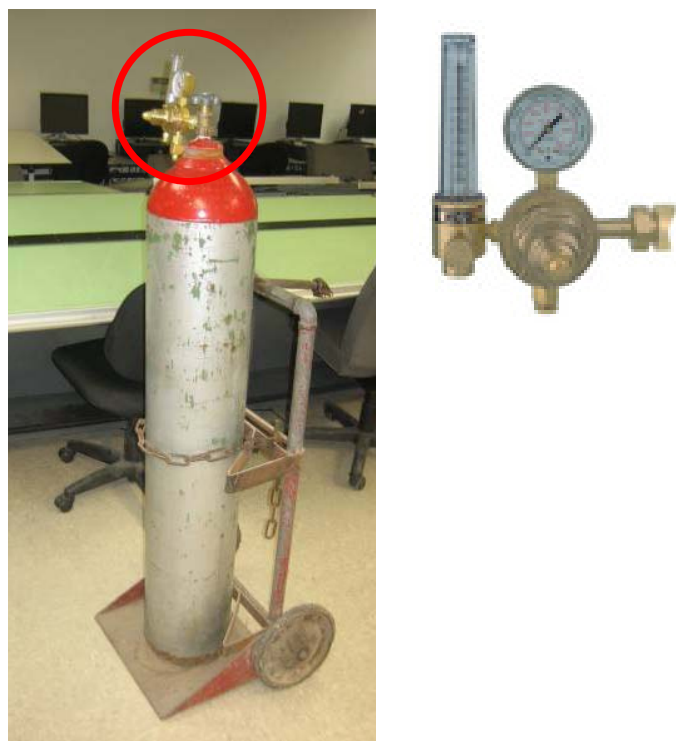

Figure 10: Compressed 2.1 UN1049 200 series hydrogen cylinder ( $\left.244 \mathrm{ft}^{3} / \mathrm{lb}\right)$ with Victor regulator and flow meter ${ }^{[27]}$
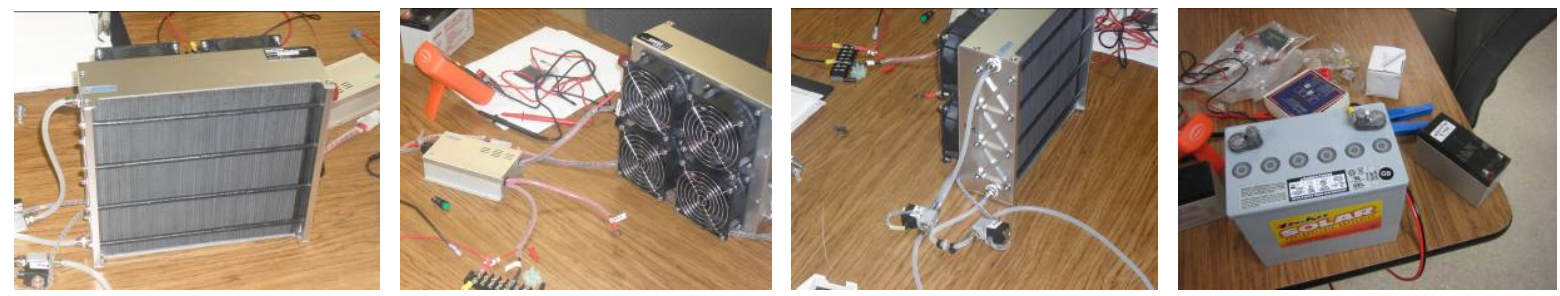

Figure 11: Assembly and testing process of H-1000 hydrogen fuel cell system

The fuel cell system was carefully evaluated and installed according to the user manual provided by the manufacturer. Initially, the system was tested without a load to determine open circuit voltage and gas flow rate. $53 \mathrm{~V}_{\mathrm{DC}}$ was measured as an open circuit voltage. Next a half empty 12V@75Ah battery was connected to determine charging current. A charging current of 21A was determined with a digital multimeter. A system setup diagram and simplified block diagram of HFCT system are shown in Figures 12, 13 respectively ${ }^{[28]}$. 


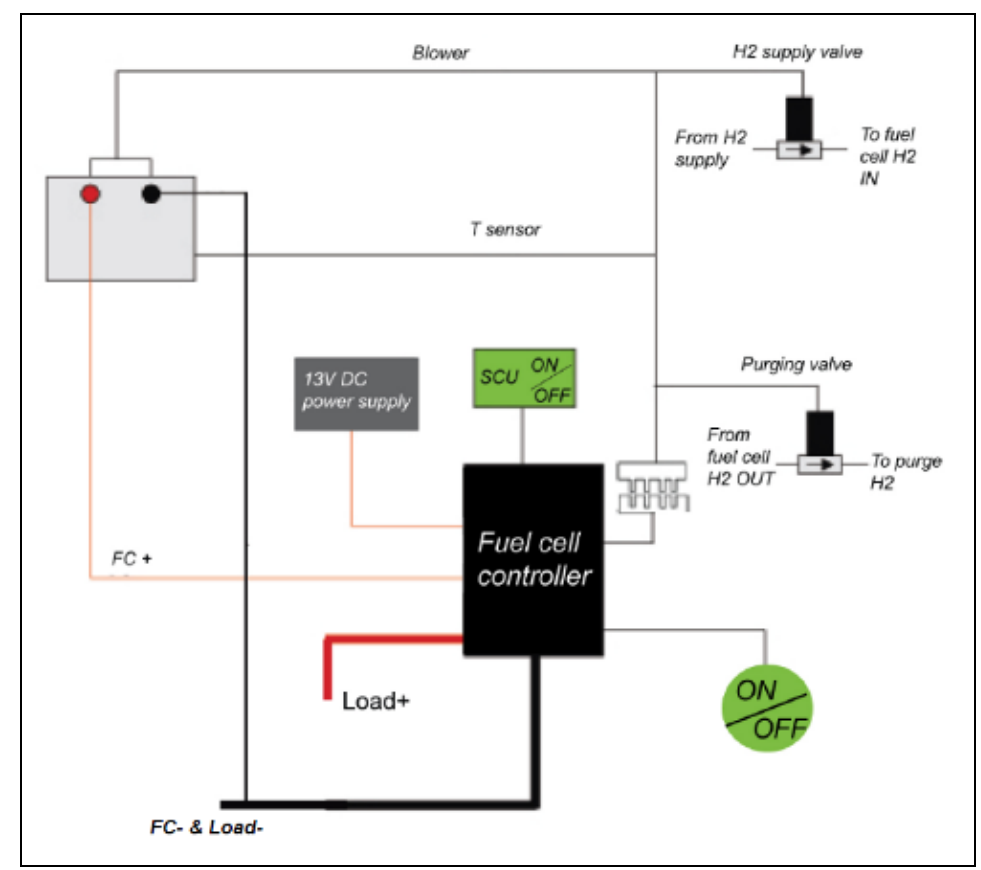

Figure 12: System setup diagram ${ }^{[28]}$

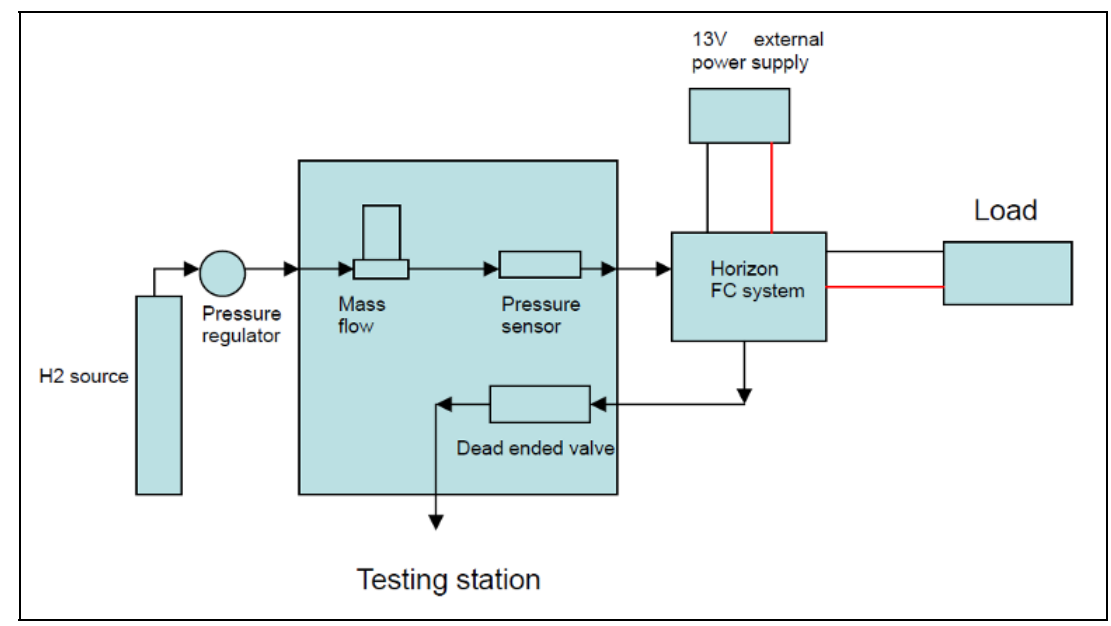

Figure 13: Simplified block diagram ${ }^{[28]}$

\section{Photovoltaic (Solar) System:}

Two 24V BP solar modules are connected in series to reach 48V to charge four series connected $12 \mathrm{~V}$ batteries. A lightening arrestor, a grounding rod, two circuit breakers, a battery fuse, a charge controller, four series connected batteries, and the two series connected solar modules were part of the overall system. The wiring diagram of the solar energy system is depicted in Figure 14 for representation purposes. Two students who took renewable energy classes in a previous semester were involved in this part of the project. The component specifications for the photovoltaic energy generation part of the project is summarized follow: 
- BP Solar Panel with polarized Multicontact (MC) connectors (BP 4170 170W 24V@4.9A)

- Charge Controller 12/24/48V@45A (Morningstar TriStar TS-45)

- DC Breaker Panel (BabyBox 4 Slot)

- Rail Mount Breaker (6 Amp Din)

- Din Rail Mount Breaker (20 Amp)

- Sealed Agm Battery (Universal Ub121350 12V@135Ah (20Hr))

- Fuse and Holder W/Set Screw Lug (Xantrex Trace 200A)

- DC Lightning Arrestor (LA302)

- Voltage/Current DC Sensors Dual

- Irradiation Sensor

- Temperature Sensor

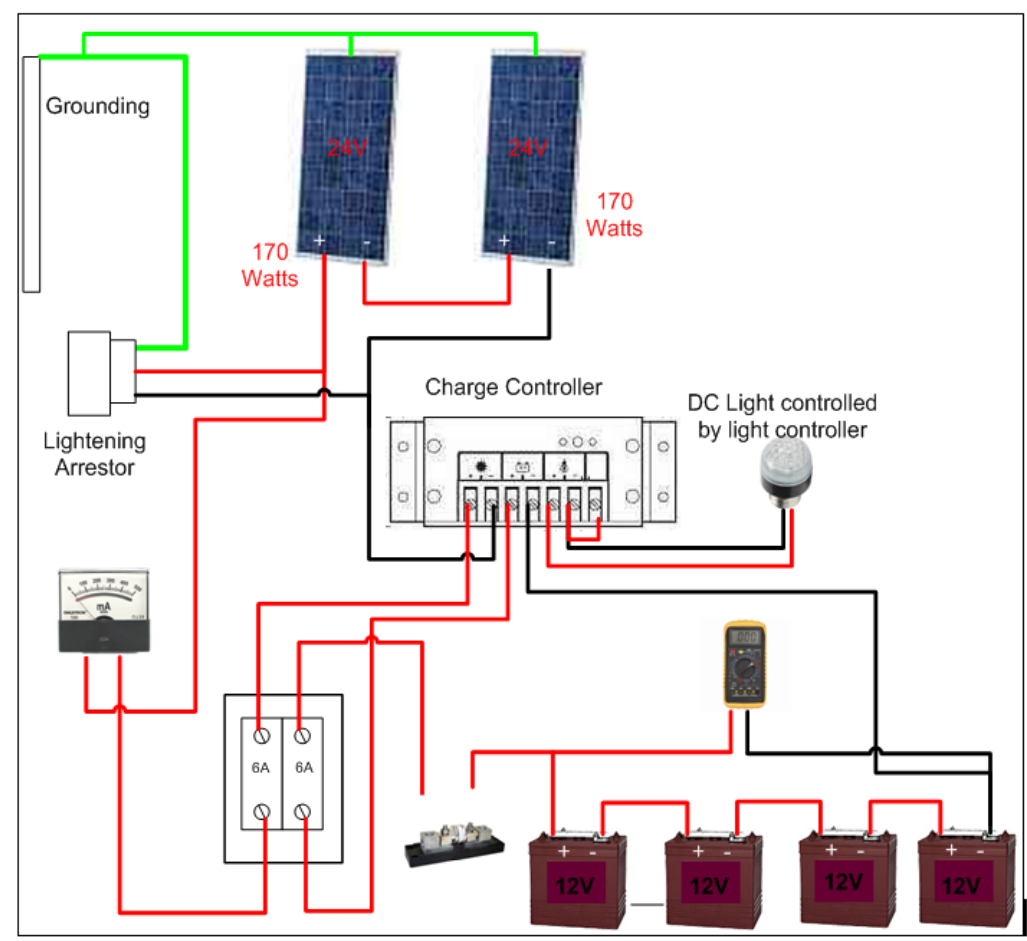

Figure 14: Solar Energy System simple wiring diagram

\section{D Model}

In engineering education, the demonstration of high tech equipment is the most common procedure. Demonstration engages process modeling, testing and simulation, and imitates data acquisition and process control. For demonstration purposes, a high level graphical user interface is required for providing efficient communication. Virtual applications may enhance both theoretical and hands-on experience for engineering and technology students by supporting laboratory experiments as well. Autodesk Inventor 2009 software tool was used to design the 3D model of the electric boat. After investigation of characteristics of the system components, the engineering design of the overall mechanical system was modeled by two design and 
development major students for demonstration purposes. All of the components' specifications were investigated and recorded in a table to design the 3D system with real dimensions. The 3D model of the boat is depicted in Figure 15.

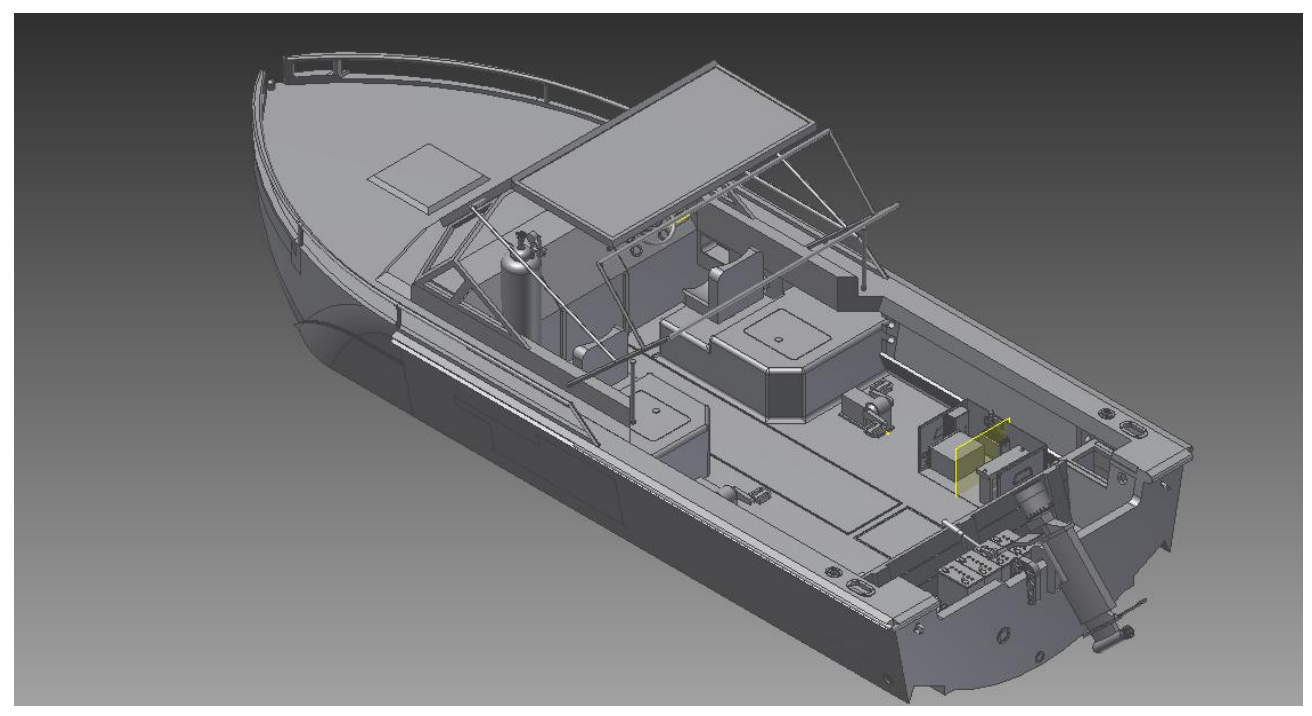

Figure 15: 3D Model of the electric boat

\section{Implementation of the Overall System}

For implementation and testing purposes, all the equipment and project components were loaded on the boat. Most of the sensitive components including the fuel cell unit, motor controller unit, and testing equipment/tools were mounted in a job box for environmental protection (the job box will be painted after tests are completed). This control box / job box will keep moisture, dirt, and dust from the fuel cell unit, controller and other electronics. In the current phase of the project, the system was tested without putting the boat on the water due to school and state paper work delays. The tests were run without any torque on the propeller in this phase, but overall test results will be presented at the conference. The overall system operated without any issues and ran smoothly until test data were generated. Since the available analog amp-meters were only $30 \mathrm{~A}_{\max }$, two measuring devices were added to the system to measure higher current, "The Cycle Analyst" and "Bogart Engineering-Tri-Metric battery system monitor" ${ }^{29-30]}$. The pictures of the components mounted in a job box and the electric boat are shown in Figure 16. Table 2 summarizes test results of the overall system. The overall power control schematic was shown in Figure 17. 

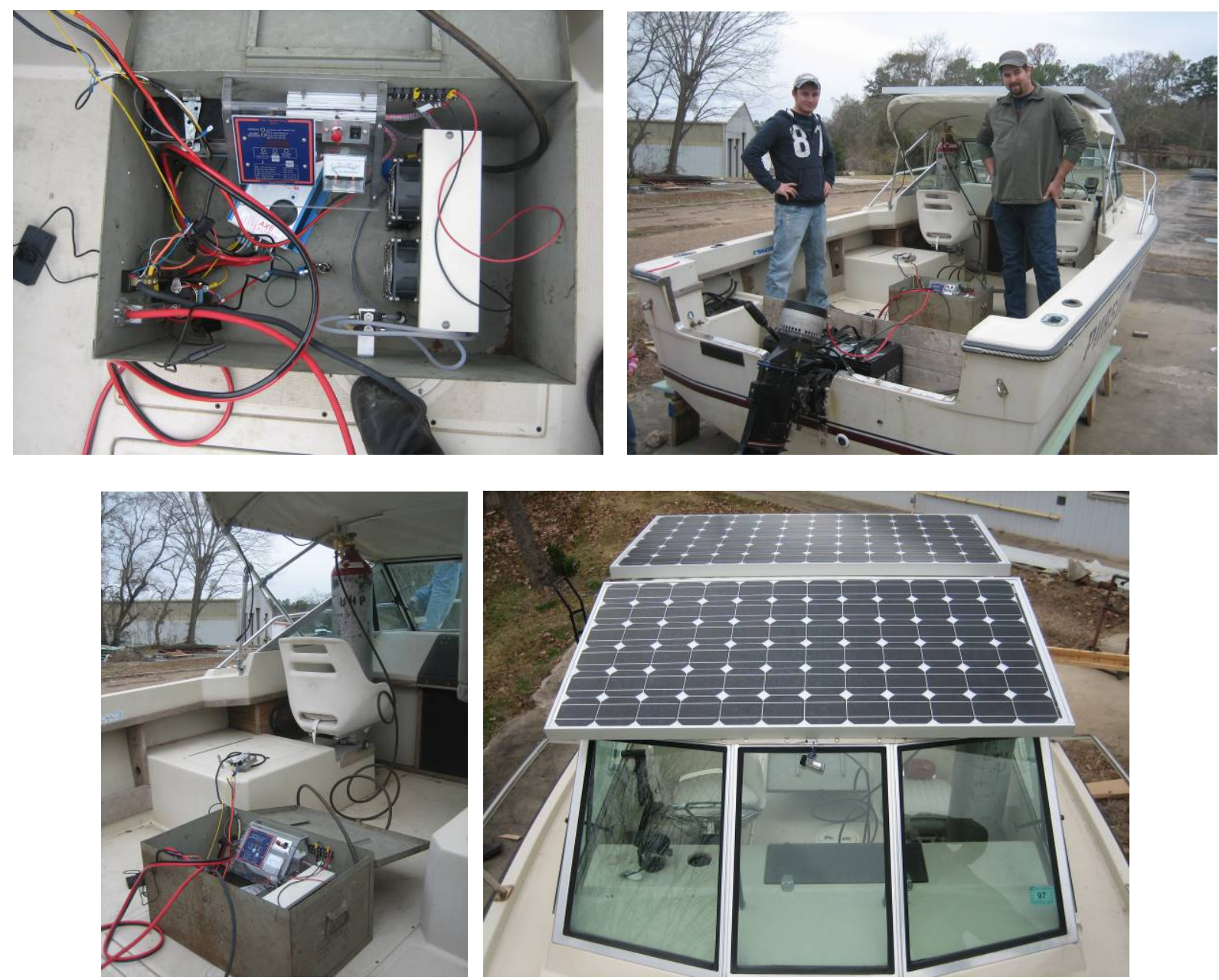

Figure 16: Electric Boat

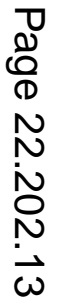




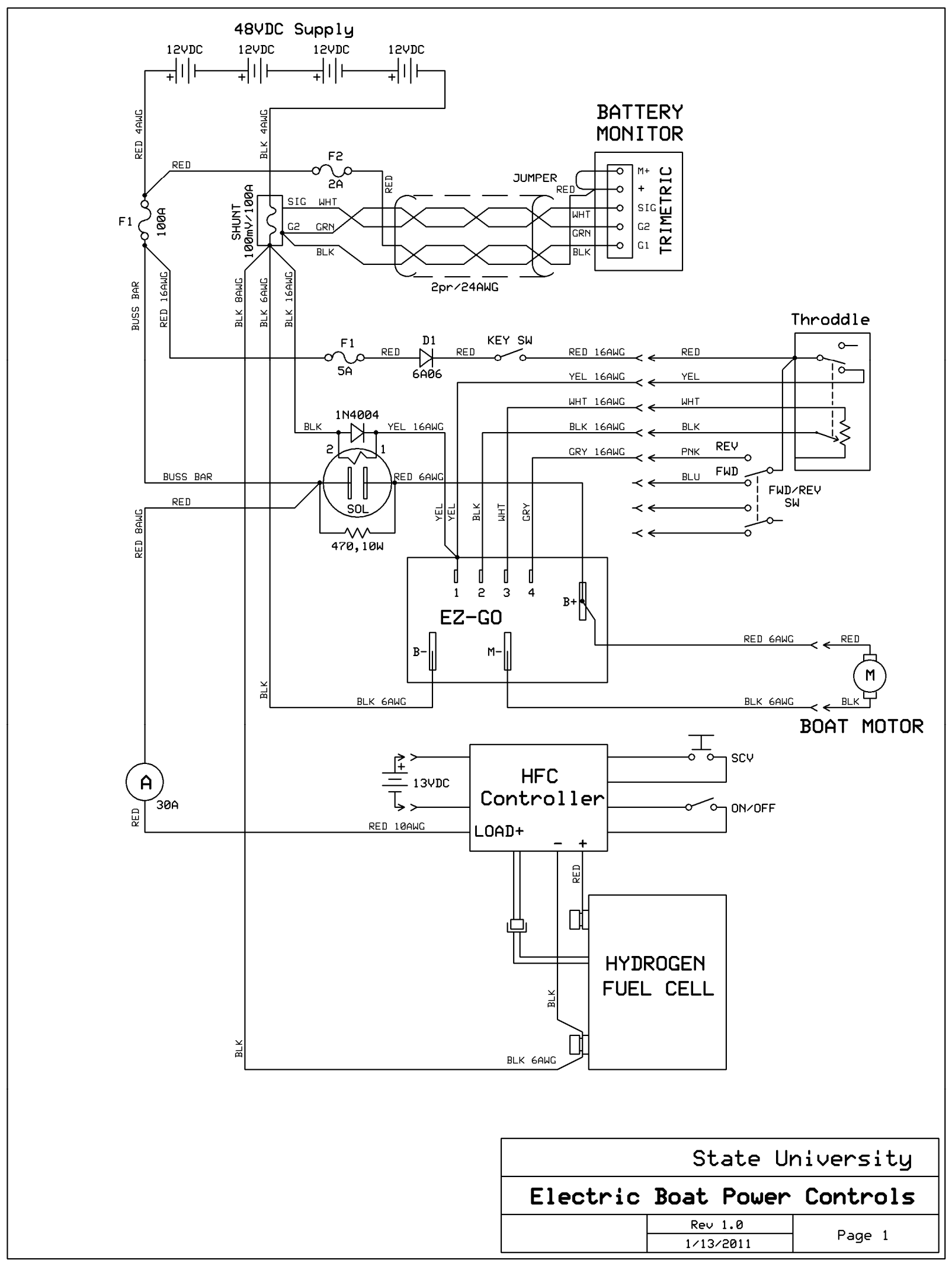

Figure 17: Power control schematic of electric boat

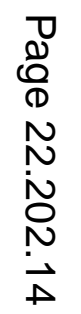


Table 2: Energy source characteristics and measured values during the testing of the system

\begin{tabular}{|c|c|c|c|c|c|c|c|c|}
\hline \multirow{2}{*}{$\begin{array}{l}\text { Energy Sources \& } \\
\text { Load (Motor) }\end{array}$} & \multicolumn{5}{|c|}{ Electrical Characteristics } & \multirow{2}{*}{$\begin{array}{l}\text { Measured } \\
\text { Current } \\
\text { (A) }\end{array}$} & \multirow{2}{*}{$\begin{array}{l}\text { Measured } \\
\text { Voltage } \\
\text { (V) }\end{array}$} & \multirow{2}{*}{$\begin{array}{c}\text { Power } \\
\text { (W) }\end{array}$} \\
\hline & $\begin{array}{c}\mathrm{P}_{\mathrm{MAX}} \\
(\mathrm{W})\end{array}$ & $\begin{array}{l}\mathrm{I}_{\mathrm{SC}} \\
(\mathrm{A}) \\
\end{array}$ & $\begin{array}{l}\mathrm{I}_{\mathrm{MP}} \\
(\mathrm{A})\end{array}$ & $\begin{array}{l}\mathrm{V}_{\mathrm{MP}} \\
(\mathrm{V}) \\
\end{array}$ & $\begin{array}{l}V_{\text {OC }} \\
(V)\end{array}$ & & & \\
\hline Fuel Cell Unit & 1000 & & 23.5 & 69 & 43 & 17.1 & 49.7 & 849.87 \\
\hline $\begin{array}{l}\text { Solar Modules X } 2 \\
\text { (Series Connection) }\end{array}$ & 170 & 5.4 & 4.9 & 34.7 & 44 & 4.6 & 48.9 & 224.94 \\
\hline Traction Motor & $\begin{array}{l}5968- \\
11190\end{array}$ & $\begin{array}{l}100- \\
300\end{array}$ & 150 & & 48 & 143 & 45.8 & 6549.4 \\
\hline
\end{tabular}

\section{Conclusion}

The goal of this project was to convert a standard internal combustion-powered boat into a zero emissions electric-powered boat. In this project, three faculty members, nine undergraduate students (majoring in construction management, design and development, electronics, and agricultural engineering technology), and two graduate students (majoring in industrial technology) have been involved since spring 2010 semester. Students participated in different phases of the project such as purchasing, mechanical integration and modifications, electrical integration and wiring, design, measurements and instrumentation, welding and aluminum casting etc. There is currently a hiring process to improve and extend the project due to graduation of senior students. Due to budget considerations students involved in this project worked either voluntary or enrolling an independent study course. Student feedbacks are very positive. Especially graduating students commented that why they were not given such extensive projects for especially student cannot get internship opportunity. It is planned to offer extensive projects on the campus for students who are willing to do internship on campus in near future. Students involved in the project experienced structured independent research, creative thinking, team work skills, and hands-on experiences with current and future systems that will have great impact on their future careers. This project will be used in a renewable energy and electronics related undergraduate course for training and hands-on lab section purposes. The topics include, but are not limited to: a) photovoltaic systems, b) hydrogen fuel cell systems, c) measurement of temperature, speed, solar insolation, voltage, current, gas flow and regulation, d) motor control systems, e) battery technology, f) circuit analysis, energy harvesting and conversion.

Students who enroll in the related classes will be asked to extend the project to an advanced level implementing more alternative energy systems to increase viability of the project. In this project, Energy harvesting systems from renewable energy sources were used to expose students to environmentally friendly equipment and vehicles. The main themes covered in the project are the needs, concepts, operation principles, modeling issues, and simulations of solar, human power, and hydrogen fuel cell systems and techniques. This project was aimed at providing students with the concepts and theoretical background, as well as the implementation of grid connection methodologies for energy harvesting. Students showing an interest in additional study and who wished to accomplish energy projects will be enrolled in directed study courses to expand their knowledge using these types of projects. 


\section{References}

[1] RiverQuest, Green Boat Project. Accessed on January 11, 2011.

http://www.riverquest.org/pdf/RQExplorer_HybridPropulsion07.pdf

[2] R. Pecen, T. Hall, F. Chalkiadakis, A. Zora, "Renewable energy based capstone design applications for an undergraduate engineering technology curriculum," FIE, Vol. 3, pp.S1E-7, 33rd Annual Frontiers in Education (FIE'03), 2003.

[3] Li Wang; Shiang-Shong Chen; Guang-Zhe Zheng; Zhi-Rong Lu; Chia-Tien Hsiung; ChenBin Huang; Cheng-Ching Huang. Installation of a 400-W wind turbine generator on a commercial fishing boat to achieve energy saving. Power and Energy Society General Meeting, 2010 IEEE, 25-29 July 2010, Pg. 1 - 6, ISSN: 1944-9925, E-ISBN: 978-1-4244-8357-0, Print ISBN: 978-1-4244-6549-1, Minneapolis, MN.

[4] Jeffrey L. Wieringa, Electric Motor Drive for A Boat. Patent Number: 5580287, December 3 1996. Accessed on January 10, 2011.

http://www.google.com/patents?hl=en\&lr=\&vid=USPAT5580287\&id=58slAAAAEBAJ\&oi=fn

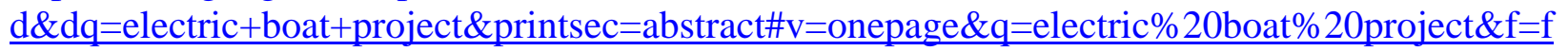
$\underline{\text { alse }}$

[5] 3.5kW Hydrogen fuel cell assisted sail boat. Accessed on December 29, 2010.

http://www.agoenvironmental.com/Under_development.htm

[6] Solar Powered Electric Boats. Accessed on January 7, 2011.

http://sunboat.com/history/history.html

[7] General Dynamics. Electric Boat. Accessed on January 11, 2011. http://www.gdeb.com/

[8] Duffy Boats. Accessed on January 15, 2011. http://www.duffyboats.com/

[9] Nauticraft Corporation. Electric Boat - The Encore E by Nauticraft. Accessed on January 3, 2011. http://www.nauticraft.com/?page=encoree\&s=2\&s2=1\&s3=3

[10] Lear Boats. LEAR 204. Accessed on January 11, 2011.

http://www.lear-electric-boats.com/Lear204.htm

[11] Jean-François Affolter, Taras Wankewycz, Jeff Davison. Compact Hydrogen Fuel Cell Solution for Recreational Fishing Boats. International Conference on Ecologic Vehicles \& Renewable Energies, 2007. Accessed on January 9, 2011.

http://www.horizonfuelcell.com/file/recreation_report.pdf

[12] ELECTRIC BOATS A - Z. Accessed on January 7, 2011. http://www.solarnavigator.net/electric_boats.htm 
[13] Student-Built, Hydrogen Fuel Cell-Powered Boat to Set Sail on Hudson River. Accessed on January 15, 2011.

http://gas2.org/2009/09/18/student-built-hydrogen-fuel-cell-powered-boat-to-set-sail-on-hudson$\underline{\text { river/ }}$

[14] First Hydrogen Fuel Cell Water Taxi on San Francisco Bay Powered by Anuvu. Accessed on January 15, 2011.

http://www.prnewswire.com/news-releases/first-hydrogen-fuel-cell-water-taxi-on-san-franciscobay-powered-by-anuvu-72561767.html

[15] Marine Hydrogen and Fuel Cell Association. Accessed on January 15, 2011. http://www.fuelcellmarkets.com/marine_hydrogen_fuel_cell_association/news_and_information/ 2,1,12828,1.html

[16] Larmine, J., Lowry, J. Modern Electric Vehicles Technology Explained. Sussex, England: John Wiley \& Sons Ltd, page 42-150.

[17] Iqbal Husain, Electric and Hybrid Vehicles Design Fundamentals. Boca Raton, Florida: CRC Press, pg. 99.

[18] Chapman, S. J. Electric Machinery Fundamentals, $4^{\text {th }}$ edition. New York: McGraw-Hill, pg. 559-561.

[19] Brush-Type Permanent Magnet DC Motor. Accessed on January 15, 2011. http://www.electricmotorsport.com/store/ems_ev_parts_motors_me0708.php

[20] Brush-Type Permanent Magnet DC Motor performance curves. Accessed on January 15, 2011. http://www.electricmotorsport.com/store/pdf-downloads/Etek_style_R_power_curve.pdf

[21] EZ-GO "Pot Box" Throttle. Accessed on January 15, 2011. http://www.electricmotorsport.com/store/ems_ev_parts_throttles_ezgo_potbox.php

[22] Alltrax AXE 4834 motor controller specifications. Accessed on January 15, 2011. http://www.alltraxinc.com/Products_AXE.html

[23] Trombeta Contactor Specifications. Accessed on January 15, 2011.

http://www.trombetta.com/dc-contactor-products.cfm?id=8

[24] CNN250 250A Fuse Specifications. Accessed on January 15, 2011. http://www.electricmotorsport.com/store/ems_ev_parts_fuses_cnn250.php

[25] H-1000 PEMFC Hydrogen fuel Cell System. Accessed on January 15, 2011. http://www.horizonfuelcell.com/store/h1000.htm

[26] H-Series PEM Fuel Cell Systems. Accessed on January 15, 2011. http://www.horizonfuelcell.com/file/H-Series.pdf 
[27] HSR2533-350 Regulator/Flowmeter Combination Units - Single And Two Stage. Accessed on January 15, 2011. http://www.welders-supply.com/Regulators.pdf

[28] Horizon Fuel Cell Technologies H-1000 Fuel Cell stack user manual. Accessed on January 15, 2011. http://www.udomi.de/downloads/H1000.pdf

[29] Cycle Analyst. Accessed on January 15, 2011.

http://www.electricmotorsport.com/store/ems_ev_parts_gauges_cycleanalyst_hc.php

[30] TriMetric Battery Monitoring System. Accessed on January 15, 2011.

http://www.bogartengineering.com/products/TriMetric 